\title{
Indonesian Online Shopping Practices in the COVID- 19 Pandemic Era: A Study of Culture and Cyber Security Law
}

\author{
Radius Setiyawan ${ }^{1,2}$, Satria Unggul Wicaksana Prakasa ${ }^{3}$ \\ 1 Doctoral Student at Social Science Department of Universitas Airlangga, Indonesia \\ 2 Faculty of Teacher Training and Education Departement of English Studies \\ Universitas Muhammadiyah Surabaya, Indonesia \\ radius@um-surabaya.ac.id \\ ${ }^{3}$ Faculty of Law of Universitas Muhammadiyah Surabaya, Indonesia \\ satria@fh.um-surabaya.ac.id
}

\begin{abstract}
Introduction to the Problems: The condition during COVID-19 that made people doing more activities at home drove the increase in spending intensity. This condition referred to a new normal. Online shopping has long been a habit for some people because of the convenience provided. In conditions of increasing online shopping activities certainly have implications for the community-online shopping practices of Indonesian people in the Covid-19 pandemic era, with an approach and cybersecurity.
\end{abstract}

Purpose/ Objective Study: This research aims to examine the relationship between online shopping practices of the Indonesian people in the Covid-19 pandemic era.

Design/Methodology/Approach: With an approach to the study of culture and cybersecurity, with integration between culture studies, economy, and digital law studies.

Findings: This research finds that massive online shopping practices in Indonesia have implications for social vulnerability. In a cultural context, people could get caught up in alienation. Online shopping activities as productive work (work to make commodities) alienate humans, four sides humans from themselves, productive work objects (instruments and productive work objects), and products consumed. While in the context of security, there was a risk of using misused personal data. It was necessary to ratify the Law of Personal Data Security as a legal regulation mechanism for sanctions for the data privacy misused in.

Paper Types: Research article

Keywords: Online Shopping, COVID-19 Era, Cyber Data Security

\section{Introduction}

IPrice, a price comparison site for various e-commerce products, summarized the Indonesian people's online shopping habits. By utilizing impression data from Google Analytics during March 2020 and February 2020. This site explained the increased interest in shopping for Indonesian people during the COVID-19 pandemic. It tracked the interest in online shopping for several products. The instrument used to determine consumer interest was impression data on Google Analytics. The data was taken by comparing the periods 1-29 February and 1-29 March 2020. Some of the 
increased products were (1) COVID-19 virus prevention product; (2) work support products from home; (3) outdoor and indoor hobby products (4)food and beverage products (Abdillah, 2020).

The COVID-19 pandemic condition has some Indonesian people do activities at home. It drives increase interest in online shopping. Online shopping activities are activities that have long existed. Liang \& Lai (2002) explained that online purchasing behaviour was the process of buying products or services through internet media. The online buying process has different steps from physical buying behaviour. The specificity of the process of buying through online media is the ease of finding information related to the goods or services that consumers need (Liang \& Lai, 2002).

It is interesting to study the phenomenon of increasing interest in online shopping. The massive shift from physical to online sites in the context of culture and security will lead to a new condition. The condition refers to a new normal (Koch, 2020), which brings new implications for people's lives, especially in Indonesia. In the context of human culture, it will be forced to minimize interaction with humans. It is a possible condition to place the machine as a centre of activity.

Technology has brought a global society into a digital society. Technology encourages people to compete and accumulate as many financial assets as possible. The disruption of technology gave birth to the urge to collect as much money as possible through a digital platform. Successful technology-based entrepreneurs showed financial accumulation are Steve Jobs (Apple), Jeff Bezos (Amazon), and Jack Ma (Alibaba). There are Nadiem Makarim (Go-Jek) and Achmad Zaky (Bukalapak) from Indonesia.

The emergence of various online shopping sites is part of life's progress. Practical, easy, and fast shopping practices are the principle of interaction in the cyber-world. Nevertheless, it is certainly not without risk. The cyber-world is very likely to degrade the quality of life and fundamental human rights. From that logic comes the term dehumanization that overshadows the technological transformation that ultimately alienates humans.

As we know, COVID-19 is the enormous use of the internet to sustain activities carried out conventionally. The data from the State Cyber and Code Agency noted that during the COVID-19 pandemic period, the online activities of Indonesian society increased by 5404 per cent, and the use of work-supporting applications from home also increased by 443 per cent. Teaching and learning activities for students and the campus as part of a school from home (SFH) or office activities massively make online activities a means of work. It includes regular trading activities and large-scale migration to the online marketplace system (Koch, 2020).

Unwittingly, various types of cybersecurity potential have been violated, such as misuse of privacy data, virus attacks (malware attacks), fraud, and online piracy 
(cyber phishing). It is also various kinds of cyber-based crimes (cybercrime \& fraud) that have the potential to violate the legal rights of the Indonesian people extensively. How does the security aspect of privacy data become something vital in this Pandemic era?

Moreover, privacy data security in Indonesia's online marketplace systems is becoming a victim of the misuse of private data. As happened in the Tokopedia case, the unicorn owned by Indonesia is known to have leaked privacy data of 15 million user accounts, this was first revealed on Twitter by the @underthebreach account on May 2, and also known that there are 91 million privacy data sold online for 5,000 US\$ (Pillay, 2020).

It dramatically impacts the security of the users. It sets a bad precedent in protecting data privacy in online marketplace systems, as e-commerce increased by a hundred percent in the middle of Covid-19. Therefore, this study tries to discuss the relationship between online shopping practices of the Indonesian people in the Covid19 pandemic era, with an approach to the study of culture and cybersecurity.

\section{Methodology}

The identification carried out in a socio-legal study was not limited to the text, but also a deepening context, including all processes, for example, from 'law-making' to 'law implementation'. The label of socio-legal studies has gradually become a general term that encompasses a group of disciplines that apply a social scientific perspective to legal studies. These included legal sociology, legal anthropology, legal history, psychology and law, a study of political science of justice, and comparative science (Lawrence, 2015).

The socio-legal approach is a combination of approaches within the social sciences, including politics, economics, culture, history, anthropology, communication, and several other sciences, combined with approaches known in law, such as learning about principles, doctrine, and hierarchy of laws. The socio-legal approach was thus the single concept for this combination. Thus, the legal analysis carried out has a broad and interdisciplinary perspective in describing the issues raised in this study (Wiratraman, 2019).

\section{Results and Discussion}

\section{Literature Review}

\section{Online Shopping Practice}

According to Aldrich British businessman Michael Aldrich discovered online Shopping in 1979 (Aldrich, 2011). Furthermore, Palmer stated that Tim Berners Lee was the one who created the first World Wide Web server and browser in 1990, then was opened for commercial purposes in 1991. Online Shopping is a part of ecommerce that refers to business activities. It utilizes communication technologies 
such as the internet as the medium (Pantelimon, 2020). E-Commerce is any form of trade transaction or trade of goods and services using electronic media. Within ECommerce itself, there is a trade via the internet, such as in business to consumer (B2C) and business to business (B2B) and trading with structured data exchange electronically (Santoso, 2020).

According to Kim, Ferrin, \& Rao The perception of benefit is consumer confidence about the extent to which it will be better than online transactions with certain websites (Kim, 2008). The concept of the word benefit refers to the extent to which a better innovation to replace existing ideas (Fonseca \& Azevedo, 2020). For example, the benefits of shopping through a website reflect consumers' recognition that this new shopping method provides certain benefits as an alternative shopping format. Customers believe that they will get a higher profit when buying online than buying through a conventional store and online Shopping can meet their needs (Saeed, 2020).

Forsythe, Liu, Shannon, \& Gardner found a positive and significant relationship between perceptions of the benefits of purchasing via the internet with the frequency of purchases and the time spent searching online. Search into e-commerce and perceived benefits had a positive effect on shopping frequency, and it also had a positive effect on online buying. It shows that the perceived benefits of online purchases will influence consumer buying behavior (Pham, 2020).

\section{Digital Alienation and Personal Data Security}

The term alienation was initially in the economic field by Marx in 1932 at his book "The Economic and Philosophic Manuscripts of 1844". He mentioned that alienation of the workers included loneliness, objectification of labor, and bondage. In the following years, Fromm used the term alienation in the field of psychology adapted from Marx.

Therefore, as a psychoanalyst, Fromm is considered a Marxian-psychoanalyst because Marx's thought had influenced his work. Somewhat different from Marx in looking at alienation, Fromm, explained that not only in the human economy experienced alienation, but also in the relationship among humans. Digital lifestyle widens alienation because people are patterned to live alone, self-service. Starting from how to eat (order via an application), how to travel (order vehicles via the application), to communication (intense communication one by one with hundreds of contacts that may not be well known, because it is easy to do and does not need to gather physically) which is also showed in the way humans shop (Madonsela, 2020).

In the point, modern society tends to communicate with a higher frequency and broader reach (throughout the world) in the digital age so that they tend to ignore the opportunity to build bridges of empathy with those closest to fill the space of alienation of their souls in the modern nature. 
Theorists of digital capitalism have sought to explore the role of non-material work in social media (Priyadarshini, 2020). Non-material work produces non-material products such as communication, information, knowledge, and social relations. Its material, non-material nature, gives rise to a disagreement about the existence of exploitation and alienation in work-play on social media. P. J. Rey, questioned the basic Marxian concept by asking whether Facebook users could consider isolated and or exploited when they were happy to provide free labor to non-profit websites (Hardt Negri Multitude; Rey, 2012).

While Fuchs dan Sevignani stated that, activities on social media had alienated humans (Saeed, 2020). They agreed that activities on social media as productive work (work making commodities) which alienated people in four ways: alienation from oneself, alienation from productive work objects (instruments and productive work objects), and alienation from the products they created (Pencole, 2018).

This four-sided forms the alienation of the entire production process caused by class relations and results in exploitation. The production process means the activity of producing content on social media that becomes data for social media corporations such as Facebook. Production facilities maintained all policies of social media platforms as a regulations of making social media corporations claim ownership of user data (Abbas, 2016).

While social media users do not enjoy the data of their work, it is what makes them alienated from the work done on social media. At the same time, they only get use value in the form of information, social relations, and specific profiles. Social media, in its development, has become a space and mechanism for expanding capital accumulation (Almohaimmeed, 2019). Data about personal information and preferences from work-play on Facebook, for example, is a commodity for social media corporations to sell to other corporations in the form of advertisements. The advantage of advertising on Facebook is that advertisements targeted personal data of Facebook users. That is different from advertising in public media such as TV, Radio, Newspapers, or Billboards, advertisements aimed at everyone or specific demographics. Advertisements cannot be targeted at specific individuals because advertisers and global media do not have information about particular users and cannot reach them (Almohaimmeed, 2019).

In studies related to alienation, indeed, more are concerned with the use of social media. Market place as a shopping site has not much related to alienation practices in the cyber world. It is what drives this analysis besides in the cultural context, referred to as alienation. The context of user data security is an essential part of the topic of this study.

\section{Online Marketplace System}

Classical economic law has given a signal related to how to carry out trading systems and mechanisms. If there is demand (supply) happens in the e-commerce mechanism 
needed by sellers and e-service providers -commerce sees the opportunity that privacy data from online consumers makes it easy to find and sell products as desired precisely and effortlessly, even though this violates the privacy rights of online consumers themselves.

Definition of an online marketplace system, according to Albert J. Marcella Jr. and Carol Stucki The collection and use of personal information for marketing purposes related to the Online Marketplace System as ways of collecting personal information online for business purposes. In addition to violating consumer privacy rights, this is also a form of ignoring the principles of trust built between consumers and ecommerce service providers, which are carried out by online marketplace system platform providers (Albert J. \& Carol, 2003).

Furthermore, the cookie technology used for online marketplace system platform providers aimed to gather various kinds of product search preferences. It becomes a basis for knowledge and interest from potential buyers and knowledge for online marketplace system platform providers. The advertisements which are suitable to be marketed persistently to candidates the right buyer; this can be known through actions taken by potential buyers such as repeated access to a site; interaction; keywords; Product content searched online; the like. At least that is what Rosemary Jane described to define the online marketplace system (Hoel \& Chen, 2018).

The online marketplace system also affirms the same meaning, which in its understanding as to the use of online media access to enter the undesirable rights of privacy of individuals of online consumers. It aims for commercial and industrial interests so that potential consumers are ad-targeted towards the product they interested in (Adams, 2017).

\section{Online Shopping, Alienation of Cultural Studies, and Socio-Legal Perspectives}

COVID-19 virus prevention health product. The interest in shopping for health products online has increased significantly. Hand sanitizer which is a preventive product for spreading the virus with the highest shopping interest, is 5,585\%, followed by vitamin $C$ with an increase in shopping interest of 1,986\%. Increased interest in Shopping has an impact on the high demand for hand sanitizer products. Up to $100 \%$ increase in retail stores and make many buyers switch to buy hand sanitizer products online on e-commerce platforms (Fonseca \& Azevedo, 2020).

The product supports work from home. The widespread of the COVID-19 virus in Indonesia has caused many companies to implement work from home activities, aka work from home (WFH). For the Jakarta area, the implementation of WFH starts from April 3, 2020, to April 19, 2020. However, many companies have implemented WFH starting in mid-March. Change in trends working from home has influenced the trends in Indonesian online shopping interest. The high intensity of online meetings and video conferences increased webcam shopping interest up to 1,572\% (Khrais, 2020). 
Outdoor and indoor hobby products, shopping interest in Polygon bikes had increased to 1,036\% since March 2020, compared to February. Not only in Indonesia, the trend of increasing purchases of indoor and outdoor bicycles is also increasing in the UK. Reported from BBC News, bicycle products have increased sales by $15 \%$. While the latter is food and beverage products, it predicted the trend of purchasing food online during the lockdown process or social restrictions. Interest in shopping instant noodles increased by $159 \%$. In addition to Indomie products, which are local instant foods, local beverage products had also increased.

In a cultural context, the shift in physical activity to digital activity has logical consequences. Human interaction with humans directly automatically will be drastically reduced. In that context, humans trapped in a condition called alienation. Fuchs and Sevignani emphasized that activities on social media or similar sites have alienated humans. They see activities on social media as productive work (work making commodities) that alienates people in four ways: alienation from oneself, alienation from productive work objects (instruments and productive work objects), and alienation from the products they create (Saeed, 2020). Online shopping sites in the form of social media or marketplaces in the COVID-19 pandemic era were very likely to place humans in an isolated position. Some things in the cultural context of alienation are as follows:

First, alienation occurs because it reduces or limits human interaction caused by the COVID-19 pandemic. Humans shift from physical encounters to digital activities. The absence of interaction between humans removes something important, namely touch and encounter. The need to be able to interact is impossible to bind humans and eventually confine humans in a new abstract prison called "cyberspace" (Pillay, 2020). Unconsciously maybe even humans will be increasingly bound and even then controlled by an online shopping site (marketplace) on behalf of needs. Humans, in the end, instead of being a whole human being with technology development, but somewhat alienated by their dependence on the needs of the technology (Tomasini, 2020).

Second, through algorithms in digital machines, humans seem to be given a choice of shopping products when they are not. When entering the shopping site, there is a tendency for producers to control their tastes and daily consumption patterns. Inability to get out of that thing we call alienation. They see consumption as an act of manipulating society, which results in humans' separation from a more authentic social existence that is relevant. Paul du Gay revealed the fact that most consumers engage in consumption activities primarily for self-determination (Talarico, 2020).

Paul du Gay et al. tracing the concept of social differentiation that was put forward by Thorstein Veblen, who states that no matter how poor a person is, his consumption action does not only lead to use-value but always leads to 'identity value'. In this case, the benchmark is, of course, the ongoing trend in society. Also, as stated by Bourdieu, 
consumption is at the same time related to material objects and symbolic activities (Hart, 2020). The objects of consumption come to us at once as material objects and symbolic shapes. Determining self-status is found by consuming image products outside can elevate his identity. The outer identity here is the relationship between high prices and famous and unique brands (Du Gay, Hall, Janes, Mackay, and Negus, 1997). It is self-alienation where consumers fall for the real image.

In Baudrillard's thinking, the lifestyle of consumption in consumer societies was because of the change in focus of attention in capitalism itself, where production management in classical capitalism has been replaced by consumption management in global capitalism (the change from "mode of production" to "mode of consumption" (Carreño, 2020). This consumptive lifestyle is controlled entirely by marketing techniques that dominate the entire awareness of consumer society, especially regarding self-differentiation. Thus, consumer societies will see their self-identity or freedom to project desires on industrial goods.

Consumption is an attempt by the community to seize social meanings or social position. Relationships no longer occur between humans but between humans and consumables. People who have become consumers will see advertising as a teacher and moral example to follow because advertising is the spearhead of capitalism as a teacher and a role model of hedonic morality. This explanation reinforces that true capitalism does not provide choices for the products presented to consumers. Instead, it tends to unconsciously force consumers over products that appear on online shopping sites (Dinu, 2016).

Third, online shopping in shopping sites requires that everyone register for their data. The practice of submitting personal data to a producer was a moment where the loss of personal and confidential data started-submitting personal data to allow producers to control ourselves in making choices about our tastes, an extraordinary thing in humans. Not when there is an abuse of personal data. User data information processed into trends in behaviour patterns that are crushed by capitalists through the temptation of advertisements and products milling about on mobile pages. Behavioural data is then transformed into a surplus of behaviour when calculating algorithms and artificial intelligence (artificially intelligent) that process behavioural data to produce predictions of user social interaction to information consumption patterns.

Besides, the vulnerability of personal data security in the digital world for some Indonesian people is windy because it is so intense and intimate that people depend on social media or shopping sites. We readily agree to the provisions regarding our data without careful consideration. All kinds of expressions, photos, activities, professions, and habits are easily uploaded on Facebook, which has 2 billion users worldwide. All done in the name of freedom and convenience, even though 
guarantees for data protection are not yet available. Guarantees for such important protection seem to be done by countries in the world.

\section{Data Privacy in the Online Marketplace System Legal Studies}

By definition, Anup K. Gosh describes the privacy policy as "... a description of a Web site's practices located in one place on the site and may be easily accessed. Every organization involved in electronic commerce transactions has a responsibility to adopt and implement a policy for protecting the privacy of individually identifiable information" (Director \& Centar, 2009).

The privacy policy is a complete description stating the responsibilities and implementation of these provisions to protect the privacy rights of an individual who has revealed his data in e-commerce activities. In every transaction of e-commerce, the privacy policy easily accessed, and this is because these provisions become very important in e-commerce activities as a code of conduct that the parties respect. The impact of unprotected privacy policies will have implications for the collection of information for parties who use the platform marketplace online platform and submit it to third parties irresponsibly through cookies (Ye, 2016).

\section{Principles Built-in Data Privacy}

Ginkhaef Simon Ginkhaef built the principles on data privacy based (Wolfe, 2019). The existence of privacy data at the beginning of e-commerce is a guide for online marketplace system providers not to violate since it becomes the basis for good faith between the parties in conducting e-commerce activities, namely:

1. Mandatory registration of data systems that are very confidential.

2. For recorded privacy data, efforts must be made for the data owner to find out how private data is used.

3. For the owner of privacy data, efforts must be made available to prevent the use of private data that is incompatible/contrary to the agreement agreed in the privacy policy.

4. There must be a way for the owner of personal data to change and improve their identity.

5. Every party that has violated the terms of the privacy policy by collecting, misusing, and disseminating privacy data must take steps to recover, compensate, and safeguard it again at a later date.

These principles become a guideline for both consumers and e-commerce providers, and online marketplace system providers to meet the provisions at the beginning of conducting e-commerce activities. Privacy policies must be adhered to in the economic relations rules.

\section{Purpose and Benefits of Privacy Data Settings}

The most critical purpose of privacy data that needs to be safeguarded in e-commerce activities is to provide legal certainty to consumers of personal information inputted and or preferences carried out in electronic transaction activities that are not misused 
and kept confidential. Since it is related to other matters with consumer human rights, it also related to the efforts of e-commerce service providers and online marketplace system providers to avoid violations of the sense of security and comfort and dignity of the consumers themselves.

The benefits achieved in setting privacy policy on e-commerce activities if carried out and adhered to properly by both parties, namely:

1. To increase security and trust between online consumers and e-commerce providers.

2. To protect the privacy rights of online consumers in e-commerce activities undertaken.

3. To create a fair business competition climate in every electronic transaction activity.

4. To build an appropriate legal settlement under the agreed privacy policy if, in the future, consumers of privacy rights are violated.

\section{Data Privacy, Covid-19, and Threats}

Data privacy, which in this digital era is something fundamental to be protected, even a part of human rights protection, needs to be protected through adequate legal and policy instruments. Especially during the COVID-19 situation, various kinds of activities are carried out online, in the online marketplace system activities. The government needs to create a legal framework and specific legislation as outlined in a transparent policy. To regulate the procedures, use, control, monitoring, and evaluation, as well as the designated authority to deal with the misuse of private data usage (Zwitter \& Gstrein, 2020).

Various kinds of potential violations that will occur in violation of privacy data in the middle of the COVID-19 pandemic are (Hoel \& Chen, 2018):

1. The potential use of big data for unethical purposes

2. Potential to manage privacy data in order to produce personal data information that cannot be recognized as truthful and biased

3. Various kinds of challenges to privacy and security data that are directly related to destructive efforts include (including published critical data).

4. Undermine and exploit human values that have been protected by law as part of the struggle for data privacy for third parties (which have nothing to do with B2C relations in the online marketplace system)

Violation of privacy data that aims to be submitted/traded by an online marketplace system provider indicates that the safeguarding of the privacy system is not going well. Misuse of the data because of gadgets during the Covid-19 pandemic became a cybercrime that needed to be overcome. By using various approaches to protect data security, privacy can be optimally carried out by all COVID-19 affected countries (Jain, 2019). No exception for Indonesia, where e-commerce actors are extraordinarily large and potentially violated their privacy rights. So, there is a legal effort that can be 
understood by the public to be able to advocate for their privacy rights violated in ecommerce activities.

\section{Violation of Data Privacy in the Online Marketplace System in Indonesia}

Concerning the violation of privacy rights experienced by consumers in the online marketplace system, it takes a preventive/caution step from consumers to include their private data, including hobbies and trends, because when the company has tabulated it, the privacy rights of the consumer themselves violated. So far, public complaints have been reported to the e-business directorate, the majority of the Ministry of Communication and Information related to incompatibility of goods ordered with goods received, for cases related to privacy rights been no complaint report (Priscyllia, 2019).

A 2013 report by the United Nations Conference on Trade and Development (UNCTAD) noted that 2,100 incidents that had consumed many losses in privacy data estimated that 822 million data had been recorded in e-commerce activities and collected in the online marketplace system. Nearly 152 million names, consumer identities, password encryption, debit, and credit card numbers, as well as information about what consumers expect to buy/consumer, recorded requests. If in percentage, the business sector actors are around $53 \%$ of the total number of parties who violated privacy data, and the purpose is for business purposes, privacy data that is often collected is account password, account username, and conversations in email.

Meanwhile, a specific case cannot be disclosed that addresses complaints of violation of privacy rights for online consumers in Indonesia. However, almost the sites in Indonesia collect consumer privacy data traced. Even some online buying and selling sites in Indonesia do not include privacy policy provisions and disclose the profiling of potential buyers. It does also not provide a description of prospective buyers to the seller of goods without the permission of the buyer itself and includes related to payment procedures only, the site in question is glodokshop.com, it proves that the position of online consumers is very vulnerable to misuse of personal data for commercial purposes (Haganta, 2020).

Besides, several other sites list the protection of personal information either directly disclosed or contained in the provisions of privacy policies, shopping safety, service provisions, legal notice, up to the legal protection, such sites such as geowebindonesia.com, lipposhop.com, link.net, astaga.com. Some sites claim that they cannot be legally prosecuted for negligence caused directly or indirectly and cause loss, error, deletion, interruption, virus violation, file or email removal, and loss of privacy loss in their notifications. It was carried out by BolehMail.com. 


\section{Legal Remedy Against Violation of Privacy Data in Indonesia}

In order to protect the privacy rights from being violated by e-commerce providers and online marketplace system providers, it is possible to have legal remedies accessed by regulated online consumers, particularly in Indonesian legal mechanisms. In this context, there are two proposals related to preventive measures and measures to take action against violators of privacy data in Indonesia (Okditazeini \& Irwansyah, 2018).

Related to preventive measures, several ways need to be done both by B2C and by online marketplace system providers, namely (Pujianto, 2018):

1. Creating a privacy data protection system that includes open access to information and legal certainty

2. Providing legal protection to consumers against deceptive and misleading practices

3. Integrating the organization, development, and regulation of consumer protection in e-commerce activities in various fields.

4. Educating people about ethics in information technology to protect themselves from misuse of private data, both by business entities, online marketplace system providers, and the state.

Also, legal remedies available to victims of violations of privacy rights following Indonesian law regulations based on Law Number 18 of 2008, updated with Law Number 19 of 2016 concerning Information and Electronic Transactions, Article 26 paragraph (1) explains protection privacy rights. In the explanatory chapter, it is "privacy rights." Personal rights contain the following meanings:

1. Personal rights are the right to enjoy private life and are free from all kinds of distractions.

2. Personal rights are the right to be able to communicate with others without spying.

3. Personal rights are the right to monitor access to information about one's personal life and data. "

Law No. 11 of 2008 concerning Information and Electronic Transactions referred to in Article 41, Article 41A, Article 42, Article 43, Article 44, and Article 44A. The exemption article is about reasons for limiting privacy data for tax purposes, settling bank receivables, judicial interests in criminal cases, and requests, approvals, or power of attorney from depositors, where the bank may violate the provisions regarding bank secrecy under specific procedures. Moreover, obtain legality from the relevant authorities (Jum'ah, 2018).

Presidential Decree No. 82 of 2012 concerning the Implementation of Electronic Transactions and Systems can file a lawsuit for civil damages, meaning that the legal mechanism demands compensation from online users to the e-commerce provider whose new mechanism is available for requesting civil compensation. This violation of privacy data is broad and is not limited to mere civil elements. Then there needs to be more specific legal regulations and expand legal efforts made for consumers who 
have violated their privacy rights. Then there is Minister of Communication and Information Regulation Number 20 of 2016 concerning Protection of Personal Data in the Electronic System, which in these rules has not yet reached the protection of the principle of privacy data as a specific and absolute constitutional right of citizens (Priscyllia, 2019).

In this context, a comprehensive data privacy protection system is not adequate. Therefore, the need for the enactment of the Personal Data Security Bill as legal regulation and framework that binds the parties in e-commerce activities. Besides, there is a need for transparent and accountable supervision by relevant authorities so that the security of personal data in the use of minimized private data. The goal, both consumers and business people, can safely move on to the online marketplace system, which aims to stability and economic struggle during a global recession as a result of Covid-19.

\section{Conclusion}

Massive online shopping practices in Indonesia have implications for social vulnerability. In a cultural context, people could get caught up in alienation. Online shopping activities as productive work (work to make commodities) that alienate humans on four sides. It alienated humans from themselves, productive work objects (instruments and productive work objects), and products consumed. While in the context of security, there was a risk of using misused personal data. It was necessary to ratify the Law of Personal Data Security as a legal regulation mechanism for sanctions for the data privacy misused in Indonesia's e-commerce activities.

This weakness needs to be answered by the government and the DPR-RI through the legislative review mechanism so that consumer protection in the online marketplace system in Indonesia is more reliable protected, explicitly addressing the COVID-19 phenomenon.

\section{References}

Abbas, A. (2016). A Review Paper on Mycoviruses. Journal of Plant Pathology \& Microbiology, 7(12). https://doi.org/10.4172/2157-7471.1000390

Abdillah, L. A. (2020). FinTech E-commerce payment application user experience analysis during COVID-19 pandemic. ArXiv, 7(2), 265-278. https://doi.org/10.15294/sji.v7i2.26056

Adams, M. (2017). Big Data and Individual Privacy in the Age of the Internet of Things. Technology Innovation Management Review, 7(4), 12-24. https://doi.org/10.22215/timreview/1067

Albert J., M., \& Carol, S. (2003). Privacy Handbook Guidelines, Exposures, Policy Implementation, and International Issues. Journal of Chemical Information and Modeling, 53(9), 1689-1699.

Aldrich, M. (2011). Online Shopping in the 1980s. Annals of the History of Computing, 33 (September 1979), 57-61. http://www.aldricharchive.com/downloads/anhc-33-4-anec-aldrich.pdf

Almohaimmeed, B. M. A. (2019). The Effects of Social Media Marketing Antecedents 
on Social Media Marketing, Brand Loyalty and Purchase Intention: A Customer Perspective. Journal of Business \& Retail Management Research, 13(04). https://doi.org/10.24052/jbrmr/v13is04/art-13

Carreño, I., Dolle, T., Medina, L., \& Brandenburger, M. (2020). The implications of the Covid-19 pandemic on trade. European Journal of Risk Regulation, 11(2), 402410. https://doi.org/10.1017/err.2020.48

Dinu, D. A. (2016). Key elements pertaining to baudrillard's analysis of postmodern culture and society. Online Journal Modelling the New Europe, 18(1), 103-116.

Director, C., \& Centar, E. (2009). Privatnost I Sigurnost U Elektroničkom Poslovanju Privacy and Security in E-Commerce. Trziste/Market, 21(2), 247-260. http://hrcak.srce.hr/file/81071

du Gay, P., Hall, S., Janes, L., Mackay, H. and Negus, K. (1997) Doing Cultural Studies: The Story of the Sony Walkman. Sage Publications (in association with the Open University). (1997).

Fonseca, L. M., \& Azevedo, A. L. (2020). COVID-19: Outcomes for Global Supply Chains. Management and Marketing, 15(1), 424-438. https://doi.org/10.2478/mmcks2020-0025

Haganta, R. (2020). Legal Protection of Personal Data As Privacy Rights Of E-Commerce Consumers Amid The Covid-19 Pandemic. 4(2).

Hardt_Negri_Multitude.Pdf. (n.d.).

Hart, A., Bortolin, M., Awoniyi, O., Alhajjaj, F., \& Ciottone, G. R. (2020). A Proposed COVID-19 Testing Algorithm. Disaster Medicine and Public Health Preparedness, 14(5), e11-e15. https://doi.org/10.1017/dmp.2020.218

Hoel, T., \& Chen, W. (2018). Privacy and data protection in learning analytics should be motivated by an educational maxim-towards a proposal. Research and Practice in Technology Enhanced Learning, 13(1). https://doi.org/10.1186/s41039-018-0086-8

Jain, P., Gyanchandani, M., \& Khare, N. (2019). Enhanced Secured Map Reduce layer for Big Data privacy and security. Journal of Big Data, 6(1). https://doi.org/10.1186/s40537-019-0193-4

Jum'ah, M. N. Al. (2018). Analisa Keamanan dan Hukum untuk Pelindungan Data Privasi. CyberSecurity Dan Forensik Digital, 1(2), 39-44. http://ejournal.uinsuka.ac.id/saintek/cybersecurity/article/view/1370

Khrais, L. T. (2020). Role of artificial intelligence in shaping consumer demand in ecommerce. Future Internet, 12(12), 1-14. https://doi.org/10.3390/fi12120226

Kim, D. J., Ferrin, D. L., \& Rao, H. R. (2008). A trust-based consumer decision-making model in electronic commerce: The role of trust, perceived risk, and their antecedents. Decision Support Systems, 44(2), 544-564. https://doi.org/10.1016/j.dss.2007.07.001

Koch, J., Frommeyer, B., \& Schewe, G. (2020). Online shopping motives during the COVID-19 pandemic-lessons from the crisis. Sustainability (Switzerland), 12(24), 1-20. https://doi.org/10.3390/su122410247

Lawrence, M. D. H. (2015). Study of. 1991, 580-582.

Liang, T. P., \& Lai, H. J. (2002). Effect of store design on consumer purchases: An empirical study of online bookstores. Information and Management, 39(6), 431444. https://doi.org/10.1016/S0378-7206(01)00129-X

Madonsela, T. (2020). More eyes on COVID-19: a legal perspective: the unforeseen social impacts of regulatory interventions. Madonsela, T. 2020. More Eyes on COVID-19: A Legal Perspective: The Unforeseen Social Impacts of Regulatory 
Interventions. South African Journal of Science, 116(7/8), Art. \#8527, Doi:10.17159/Sajs.2020/8527, 116(7), 7-8.

Okditazeini, V., \& Irwansyah, I. (2018). Ancaman Privasi dan Data Mining di Era Digital: Analisis Meta-Sintesis pada Social Networking Sites (SNS). Jurnal Studi Komunikasi Dan Media, 22(2), 109. https://doi.org/10.31445/jskm.2018.220202

Pantelimon, F.-V., Georgescu, T. M., \& Posedaru, B.-S. (2020). The Impact of Mobile eCommerce on GDP: A Comparative Analysis between Romania and Germany and how Covid-19 Influences the e-Commerce Activity Worldwide. Informatica Economica, 24 (2/2020), 27-41. https://doi.org/10.24818/issn14531305/24.2.2020.03

Pencole, M. A. (2018). Digital labour. In Krisis (Issue 2). https://doi.org/10.4324/9781315768656-4

Pham, Q. V., Nguyen, D. C., Huynh-The, T., Hwang, W. J., \& Pathirana, P. N. (2020). Artificial Intelligence (AI) and Big Data for Coronavirus (COVID-19) Pandemic: A Survey on the State-of-the-Arts. IEEE Access, 8(April), 130820-130839. https://doi.org/10.1109/ACCESS.2020.3009328

Pillay, J. (2020). COVID-19 Shows the Need to Make Church More Flexible. Transformation, 37(4), 266-275. https://doi.org/10.1177/0265378820963156

Priscyllia, F. (2019). Perlindungan Privasi Data Pribadi dalam Perspektif Perbandingan Hukum. Jatiswara, 34(3), 1-5. https://doi.org/10.29303/jatiswara.v34i3.218

Priyadarshini, I., Mohanty, P., Kumar, R., Son, L. H., Chau, H. T. M., Nhu, V.-H., Thi Ngo, P. T., \& Tien Bui, D. (2020). Analysis of Outbreak and Global Impacts of the COVID-19. Healthcare, 8(2), 148. https://doi.org/10.3390/healthcare8020148

Pujianto, A., Mulyati, A., \& Novaria, R. (2018). Pemanfaatan Big Data Dan Perlindungan Privasi Konsumen Di Era Ekonomi Digital. Majalah Ilmiah Bijak, 15(2), 127-137. https://doi.org/10.31334/bijak.v15i2.201

Rey, P. J. (2012). Alienation, Exploitation, and Social Media. American Behavioral Scientist, 56(4), 399-420. https://doi.org/10.1177/0002764211429367

Saeed, N., Bader, A., Al-Naffouri, T. Y., \& Alouini, M. S. (2020). When wireless communication faces COVID-19: Combating the pandemic and saving the economy. ArXiv, 1-11.

Santoso, R. (2020). Review of Digital Marketing \& Business Sustainability of ECommerce During Pandemic Covid19 In Indonesia. Jurnal Ilmu Ekonomi Terapan, 5(2), 36-48.

Talarico, D. (2020). Marketing roundup: A look at COVID-19 adaptations across industry. Recruiting \& Retaining Adult Learners, 22(10), 3-3. https://doi.org/10.1002/nsr.30618

Tomasini, F. (2020). Solidarity in the time of COVID-19? Cambridge Quarterly of Healthcare Ethics, 1-14. https://doi.org/10.1017/S0963180120000791

Wiratraman, H. P. (2019). Pendidikan Hukum Indonesia. 31, 402-418.

Wolfe, R. (2019). Learning about Digital Trade: Privacy and E-Commerce in CETA and TPP. World Trade Review, 18(S1), S63-S84. https://doi.org/10.1017/S1474745618000435

Ye, H., Cheng, X., Yuan, M., Xu, L., Gao, J., \& Cheng, C. (2016). A survey of security and privacy in big data. 2016 16th International Symposium on Communications and Information Technologies, ISCIT 2016, September 2016, 268-272. https://doi.org/10.1109/ISCIT.2016.7751634 
P-ISSN: 1412-6834

Volume 12, Issue01x, 2021, pp. 29-44

Zwitter, A., \& Gstrein, O. J. (2020). Big data, privacy and COVID-19 - learning from humanitarian expertise in data protection. Journal of International Humanitarian Action, 5(1). https://doi.org/10.1186/s41018-020-00072-6 